Márton Pelles

\title{
The Innovative Managerial Role of Jenő de Polnay as the Key Element to the Success of the Atlantica Sea Navigation Company within the Hungarian Maritime Fleet (1907-1914) ${ }^{1}$
}

\begin{abstract}
The Atlantica Sea Navigation Company was the most innovative of the Hungarian sea navigation companies. In my study, I shall present the company's operations from its founding in 1907 until the beginning of the Great War in 1914. I shall greatly emphasise the analysis of how the company led by Jenő Polnay de Tiszasüly was able to grow in only 7 years into a shipping company that shipped with 12 modern steamships. Thanks to his previous entrepreneurial experience Polnay managed to join the Hungarian State and the Austro-Hungarian Bank to found the company. After this, he had British shipyards design steamships that were able to transport large capacity timber at low bearing depth. He then concluded beneficial deals with the Hungarian State Railways and the Transylvanian and Russian suppliers. The first application of the 'quick despatch' principle in Hungary is also bound to the name Polnay. Atlantica shipped cheaper if the ships were loaded swifter. Based on the sources of the Rijeka State Archives, I shall investigate the question how the innovative managerial skills of Jenő de Polnay attributed to the efficiency of Atlantica Co. in goods transportation and how the company became the most successful Hungarian tramp trade company of the beginning of the $20^{\text {th }}$ century.
\end{abstract}

Keywords: Groedel, Polnay, Atlantica, Maritime history, Quick despatch

\section{Introduction}

In the period between 1867 and 1918 Hungary acquired a unique independence within the Habsburg Empire resulting it having its own economic policies. ${ }^{2}$ Following the Compromise of 1867, Hungary regained its sole seaport Fiume (today: Rijeka, Croatia), which had been part of the Hungarian Crown from 1776. Within the framework of a gigantic investment, the state built a modern port in the city, which by 1910 was one of the busiest ports of Europe. ${ }^{3}$ The value of the investment was $81,318,299$ Krones (today this would be the equivalent of roughly $€ 1,069,732,802)$. The investment paid for itself through local taxes and port duties as early as 1886 , thenceforth generating profit. ${ }^{4}$ In the meantime companies from Fiume, Budapest, Liverpool and Glasgow cooperated with the Hungarian state to create Hungarian shipping companies. Among these, the biggest state-funded company was the Adria Hungarian

\footnotetext{
1 The research was supported by the ÚNKP-20-3-II-PTE-463 New National Excellence Program of the Ministry for Innovation and Technology From the Source of the National Research, Development and Innovation Fund.

2 Komlos, John: The Habsburg Monarchy as a Customs Union. Economic Development in Austria-Hungary in the Nineteenth Century. Princeton University Press. Princeton. 1983.; Berend, T. Iván: An Economic History of Twentieth-Century Europe. Economic Regimes from Laissez-Faire to Globalization. Cambridge University Press. Cambridge. 2006.; Katus, László: A Monarchia közös piaca. Magyar Tudomány XXXIV. (1989) 10-11. 808820.; Kövér, György: Iparosodás agrárországban. Budapest, 1982.; Kaposi, Zoltán: Die Entwicklung der Wirtschaft und Gesellschaft in Ungarn 1700-2000. Studia Hungarica. Passau, 2007. Schenk Verlag.

3 See: Katus, László: A tőkés gazdaság fejlődése a kiegyezés után. In: Magyarország története 1848-1890. Edited: Kovács Endre. Budapest, 1979. 2. 913-1038.; Katus, László: Magyarország gazdasági fejlődése (1890-1918). In: Magyarország története 1890-1918. Edited: Hanák Péter. Budapest, 1978. 263-402.; Andrović, Jan: Triest in seiner See- und Handelsentwicklung Goldovanni, Trieste 1918.;

4 Državni Arhiv u Rijeci (State Archives of Rijeka, hereinafter: DAR). 46: 66-1891-XIX-2317.
} 
Royal Sea Navigation Company. ${ }^{5}$ In the field of tramp trade shipping a number of shipping companies sprung up, partly due to the government providing some subsidies to these and some line support (if they transported goods that were beneficial to Hungary) too. This state presence in shipping, however, was not unique to Central Europe. The big British shipping company, the later Cunard, used state subsidies in order to create its regular Atlantic lines. It was under these circumstances that in 1907 the Atlantica Sea Navigation Company was founded. In my study I examined the question what exactly the secret was to the success of Atlantica, and what innovative tools Jenő de Polnay applied to make the company the most successful Hungarian tramp trading company in the beginning of the $20^{\text {th }}$ century.

\section{Founding and functioning of Atlantica}

The Atlantica Sea Navigation Company was founded by Jenő de Polnay November 2, 1906. This founding was preceded by serious organisation. Through their successful wood production and export businesses, the Groedel family gained enormous wealth in the second half of the $19^{\text {th }}$ century. The Groedel family had large forest areas in the North-eastern Carpathians. Originally, the family moved from Germany to Hungary. The second generation did not only produce for domestic markets but also realised significant export to the world market with all sorts of wood products. ${ }^{6}$ It was this Groedel Company where Jenő de Polnay commenced his career. He advocated that the company should not use rented ships but rather have its own fleet to export timber to the ports of Rotterdam and Britain. ${ }^{7}$ The London Groedel steam shipping company operated 4 steamships and had become so successful that in 1905 King Franz Ferdinand bestowed the title baron to the Groedels. Their crest showed forests and shipping. ${ }^{8}$ Polnay was born in 1873 to a Jewish timber merchant family. Through the Groedels, he became the president of the London shipping company, thus learning the crafts of the management of timber trade and steam shipping at sea. In 1906 he presented a new idea. He talked the Hungarian minister of commerce of then, Count Béla Serényi and the English-Austrian Bank into supporting the foundation of a new Hungarian shipping public limited company. ${ }^{9}$ In practice this meant that the Bank financed the company and the Hungarian government had article VI of 1907 accepted by parliament. This article ensured large-sized support for ship building and transportation fees to those tramp shipping companies that transported goods that were important to Hungary.

The Atlantica's capital stock was 4,000,000 Krones and 70\% was owned by the EnglishAustrian Bank. ${ }^{10}$ Apart from the bank representatives shareholders (Ignác Dóczi, Pál Engel, Gyula Landesberger) the following persons were also shareholders: Károly Morawitz politician (10 \%), Doctor Izidor Petschek (10 \%), Jenő de Polnay (2.5 \%), Béla Serényi politician and Zsigmond Kotányi (one of the leaders of the Hungarian State Railways) with one share each and count István Batthyány, retired secretary to the ministry of finance, and the relatives of the latter. ${ }^{11}$ The foundation of the company was also supported by the next minister of commerce Ferenc de Kossuth and his secretary of state baron József Szterényi.

\footnotetext{
5 Pelles, Márton - Zsigmond, Gábor: The Hungarian maritime trade history of Fiume (1868-1918). Pécs, 2018. 95-118.

6 TolnaiViláglapja,26.03.1903.https://adtplus.arcanum.hu/hu/view/TolnaiVilaglapja 1903 03/?query=groedel\&p$\mathrm{g}=3048$ layout $=\mathrm{s}$.

7 The Archives of the Hungarian Museum of Science and Transportation. (hereinafter: KEZ) 680.1.

8 Illésy, János - Pettkó, Béla: A Királyi Könyvek 3. (1527-1867). Budapest, 1895. 72.

9 DAR. 46: 415-1907-XXI-437.

10 The Atlantica Co. banner was the Hungarian tricolour (red-white-green) against a golden background with a large black letter A. Please see: Pelles, Márton - Zsigmond, Gábor: The Hungarian mariteme...170.

11 On the shareholders please see: DAR. 46: 460-1908-XX-3426.
} 
In the sense of the statutes the aim of the company was long distance shipping, to represent Hungarian commercial interests in all important ports of the world. ${ }^{12}$ The company wished to realise this by establishing agencies in the major ports. The company's seat of business was in Budapest. It was a centre employing 25 people and was led by Béla Geiger, Oszkár Solymássy E., Doctor Ödön Fónagy and Ferencz Czanich. ${ }^{13}$ In Fiume there was an office employing 3 people, in Odessa 2, in Mykolaiv 5, in Brăila 16, in Sulina 2 and in London one. ${ }^{14}$

The company basically utilised the innovative managerial ideas of Jenő de Polnay to efficiently organise their ship's traffic between the bigger ports. This included a number of arrangements. Firstly, Atlantica founded a Romanian sister company under the name of Societate Atlantica. This supervised the railway transportation of the export timber of Transylvanian Forestry Co. which was governed by the Transylvanian Groedels. Transportation that took place from the South Carpathians through the Romanian Kingdom to the Lower-Danubian ports of Brăila, Galati and Sulina. Secondly, Polnay ordered six ships from the shipyards of Gray in West Hartlepool and Thompson in Sunderland. In cooperation with the engineers of the shipyards he had ships built with lower draught to be able to go up the Danube River, respectively to load and transport as much timber in volume as possible. Thirdly, Polnay concluded an advantageous agreement with the Hungarian State Railways through Zsigmond Kotányi, who was also a shareholder in Atlantica. In accordance with the agreement, Atlantica's ships transported timber to Rotterdam and the United Kingdom and on the return trip brought back coal to Fiume. Coal was used by the steam engines of the railways. To avoid shipments halting due to the Danube being frozen in winter, Polnay also connected to the cereal export business in the Sea of Azov region through his Mykolaiv and Odessa agencies. ${ }^{15}$ Fourthly, these transports carried import and export articles that were of importance to Hungary. Polnay created a possibility for Atlantica to access the subsidies determined in article VI. of 1907. Fifthly, it was Polnay that first utilised the quick despatch principle in maritime shipping in Hungary. This meant that Atlantica in many cases grossly overpaid the loading dock workers and transported goods at cheaper tariffs than the competition if the ships were loaded quicker. These innovative measures created the key to the success of Atlantica. ${ }^{16}$ For making the company successful and results reached in the development of Hungarian maritime merchant shipping, Polnay received a Hungarian title of nobility in 1911 from Franz Joseph, the title being: de Tiszasüly. ${ }^{17}$

Regarding payments, the Hungarian shipping companies would have generally differentiated based on the role a given employee fulfilled within the company and the amount of years the employee had worked at the given company. The shipping companies generally differentiated two categories in case of clerks, four categories for engineers and three categories each for captains and lieutenants. This differentiation, however, was not uniform. It can be stated that among the Austro-Hungarian maritime shipping companies Atlantica paid the best wages to its employees. This was in unison with the quick despatch principles, since the Atlantica ships were working in the evenings and on Sundays too. This resulted in pays as follows: clerks 180-264 C a month; naval officers on board $120 \mathrm{C}$; engineers $120-400 \mathrm{C}$; captains $400-450 \mathrm{C}$ a month. ${ }^{18}$

\footnotetext{
DAR. 46: 539-1910-II-2768.

The old Atlantica Palace can still be found in Budapest, Falk Miksa street 18-20.

DAR. 46: 583-1911-II-3058.

For more on Azov Sea Region cereal trade sea: Sifneos,Evrykiki: Greek Family Firms in the Azov Sea Region, 1850-1917. Business History Review 87 (Summer 2013): 279-308.

16 Polnay's managerial innovations were recorded in the work of dr. Bíró, Elek: KEZ. 680.3.

17 Illésy, János - Pettkó, Béla: A Krályi Könyvek...166.

18 DAR. 46: 8-1908-IV-263; DAR. 46: 732-1914-I-4232.
} 


\section{Atlantica's commercial fleet}

When the company was founded in 1907, it operated with six modern ocean liners; four of them were constructed based on the same design in West Hartlepool (SS Szterényi, SS Magyarország, SS Gróf Serényi Béla, SS Polnay) and two were built in Sunderland (SS Kossuth Ferencz, SS Morawitz). In accordance with the practice of those days, the company's steamships were named after their own shareholders and politicians that helped the founding of the companies. The Szterényi type steamships provided 3,665 gross register ton volume resulting in 2,665 nett register ton transport capacity and 5,250 ton bearing capacity. The Sunderland Kossuth Ferencz type steamers had 4,790 GRT and 3,100 NRT with 7,000 ton bearing capacity. ${ }^{19}$

An excellent example of Polnay's commercial resourcefulness was that by taking advantage of shipping subsidies as per the law of 1907 , he purchased a relatively small ocean liner, the SS Tenger (1,220 GRT, 857 NRT, 2,000 ton bearing capacity). After this, they performed the necessary minimum obligation of the 1907 Law on Tramp Shipping (2-3 transport with goods important for Hungary). The steamboat was sold towards the end of 1911 and the request for subsidy was handed in to the State for the year 1912 granting the company a total amount of 97,600 Krones. ${ }^{20}$

By attracting new shareholders, the company expanded its stock capital to 6,000,000 Krones in $1911 .{ }^{21}$ Increase in stock capital was necessary for the company to build new steamboats. The SS Budapest and SS Fiume were built in Stockton on Tees, each with an approximate 3,655 GRT and 2,325 NRT and 5,300 tons of bearing capacity. There were also three new steamships built in Newcastle: the SS Gróf Khuen-Héderváry and the SS Atlantica with 4,990 GRT, 3,240 NRT capacity and 7,200 tons of bearing capacity, and the SS Hunnia with 2,233 GRT, 1,383 NRT capacity and 3,500 tons of bearing capacity. In the four years between 1907 and 1910, the company disposed over 15,873 NRT capacity and between 1911 and 1914 28,598 NRT clean transportation capacity. For the steamships, the company received a total subsidy for ship acquisition of 3,531,730 Krones until 1918. ${ }^{22}$

\section{The company's ship and goods turnover}

The Atlantica ships' goods turnover can be reconstructed with the help of excerpts of shipping journals of the transports. ${ }^{23}$ These sources clearly indicate that the commercial agencies created by the company played a crucial role in the turnover of the company. Until 1912 the company had to ship with chartered steamships too due to the large number of orders. Atlantica's own ships concluded 483 shipments over 1,723,331 nautical miles from the founding of the company until the break out of the Great War. The chartered steamships added another

19 DAR. 46. Ship register. 241.

20 DAR. 46. 623-1912-I-128; Hungarian State Budget 1912:895-898. https://library.hungaricana.hu/hu/view/ AllamiKoltsegvetes 1912/.

21 DAR. 46: 630-1912-II-636.

22 Hungarian State Budget 1917-1918:979-980. https://library.hungaricana.hu/hu/view/AllamiKoltsegvetes $1917-1918$

23 DAR. 46: 112-1894-XXI-2795; 151-1897-XXIII-5234; 216-1900-XXI-7; 242-1902-XXI-4; 2841904-XXI-805; 284-1904-XXI-940; 284-1904-XXI-1310; 284-1904-XXI-1148; 316-1905-XXI-55; 316-1905-XXI-296; 316-1905-XXI-1040; 316-1905-XXI-2336; 364-1906-XXI-2; 365-1906-XXI-1440; 365-1916-XXI-2713; 365-1906-XXI-5512; 415-1907-XXI-321;415-1907-XXI-437;415-1907-XXI-800; 416-1899-XXI-4206; 459-1908-XX-205; 460-1908-XXI-2; 460-1908-XXI-360; 460-1908-XXI-2207; 4961909-II-134; 496-1909-II-161; 496-1909-II-307; 496-1909-I-5599; 497-1909-III-596; 538-1910-II-117; 538-1911-II-3583; 581-1911-II-72; 582-1911-II-173; 623-1912-I-128; 623-1912-I-134; 629-1912-II-147; 630-1912-II-816; 630-1912-II-3906; 675-1913-I-1931; 676-1913-I-3365; 678-1913-II-132; 679-1913-II132; 682-1913-II-911; 682-1913-II-1951; 682-1913-II-9104; 729-1914-I-707; 733-1914-II-50; 730-1914I-927; 732-1914-I-4232. 
368,922 nautical miles to this. ${ }^{24}$ Concerning the turnover of the Atlantica ships, I have created a network illustrating which ports were connected by the company and with what size of goods turnover. From this network I shall show the graph on transports of more than 15,000 tons (Illustration 1).

\section{Illustration 1: Network of ports between 1907 and 1914 connected by Atlantica's own steamers with more than 15,000 tons of goods turnover}

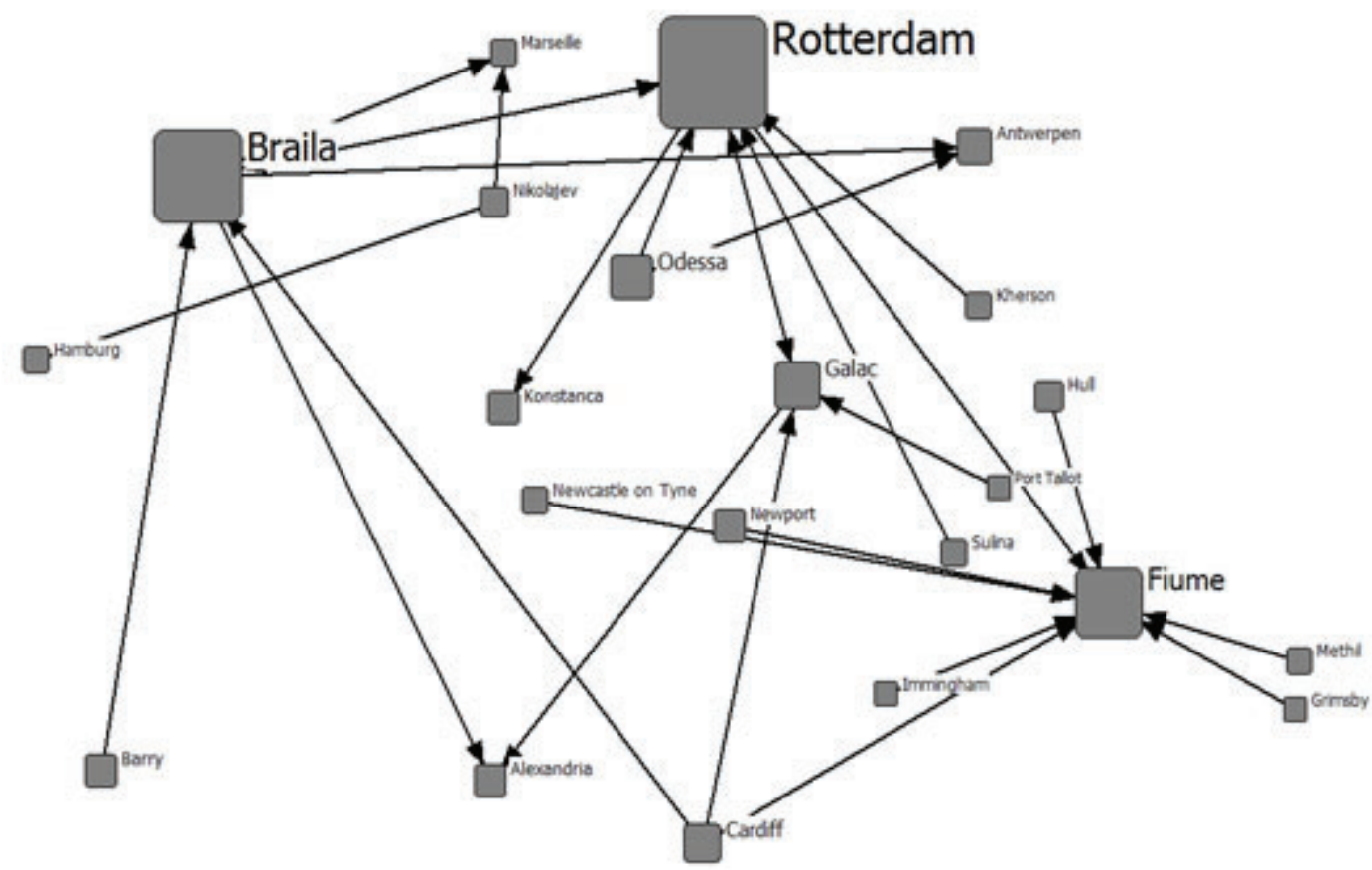

Source: Documents indicated in footnote 23. in the Rijeka State Archives from Atlantica shipping journals

Atlantica's goods turnover could be divided into three groups. As the illustration shows, timber and cereals were transported by more steamers from the Lower Danube and Black Sea ports to Alexandria and Rotterdam and from the Dutch and English ports (e.g. Cardiff) coal and coke to Fiume and the Lower Danube ports. On the other hand there were typical Hungarian transports to gain shipping subsidies to Hungary such as raw rice from Indonesia for the rice mills of Fiume; phosphates from the Christmas Island or cotton from the southeastern ports of the USA. Finally, there were other tramp shipping transports between the other ports of the world. The latter meant that the company's ships travelled as far as South America (Rosario Santa Fe and Buenos Aires) North America (Tampa, Baltimore and Port Inglis) Asia and Oceania (Karachi, Bombay, Colombo, Calcutta, Akyab, Moulmein, Christmas Island and Africa (Oran, Port Said, Alexandria and Tripoli). In Europe the ships ventured to British, Norwegian, Spanish, French, Dutch, German, Italian, Turkish, Greek, Romanian and Russian Black Sea ports from Fiume, Trieste and Buccari. The total of the company's goods turnover is shown in illustration number 2 .

24 The definition of a nautical mile is 1852 metres. 


\section{Illustration 2: Yearly goods turnover of Atlantica between 1907 and 1914 in tons with their own and chartered steamships}

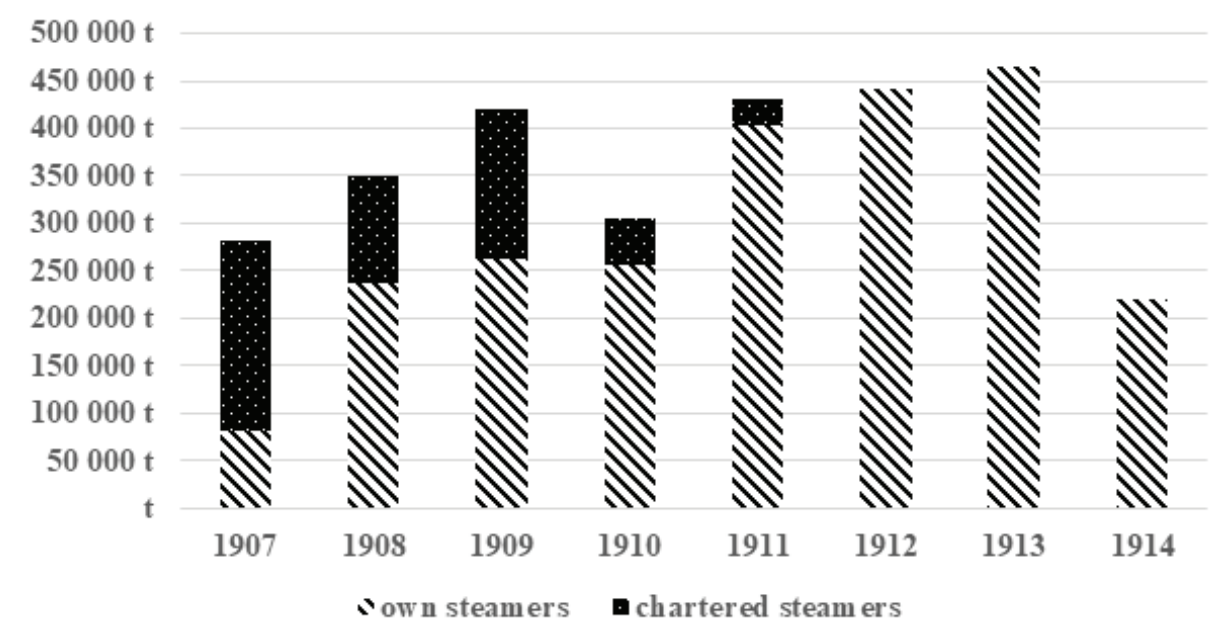

Source: Documents indicated in footnote 23. in the Rijeka State Archives from Atlantica shipping journals

The total of Atlantica's goods turnover between 1907 and 1914 amounted to 2,912,162 tons of goods. $19 \%$ of this was by chartered steamships $(543,125 \mathrm{t}$ ) and $81 \%$ by own steamships $(2,369,037 \mathrm{t})$. If by revisiting illustration 1 . we investigate how big the role of the weighted goods turnover of the individual ports was in the existence of the company we can conclude that the steamers transported $27 \%$ of the total goods to Danube ports, $19 \%$ to Rotterdam and $10 \%$ to Fiume.

In this timeframe, there were also other tramp shipping companies operational within Hungarian maritime commercial shipping. Between 1893 and 1913 the Hungarian Oriente Shipping Company Limited, between 1895 and 1912 Copaitich and Partners Company Limited, between 1896 and 1908 Photogen Transport Company Limited, between 1900 and 1913 Hungarian-Croatian Free Shipping Company Limited, between 1901 and 1913 the Indeficienter Company Limited, between 1903 and 1913 Pajkurich Company Limited. ${ }^{25}$ Based on these, the following, illustration shows the overall goods turnover of the Hungarian tramp shipping fleet globally.

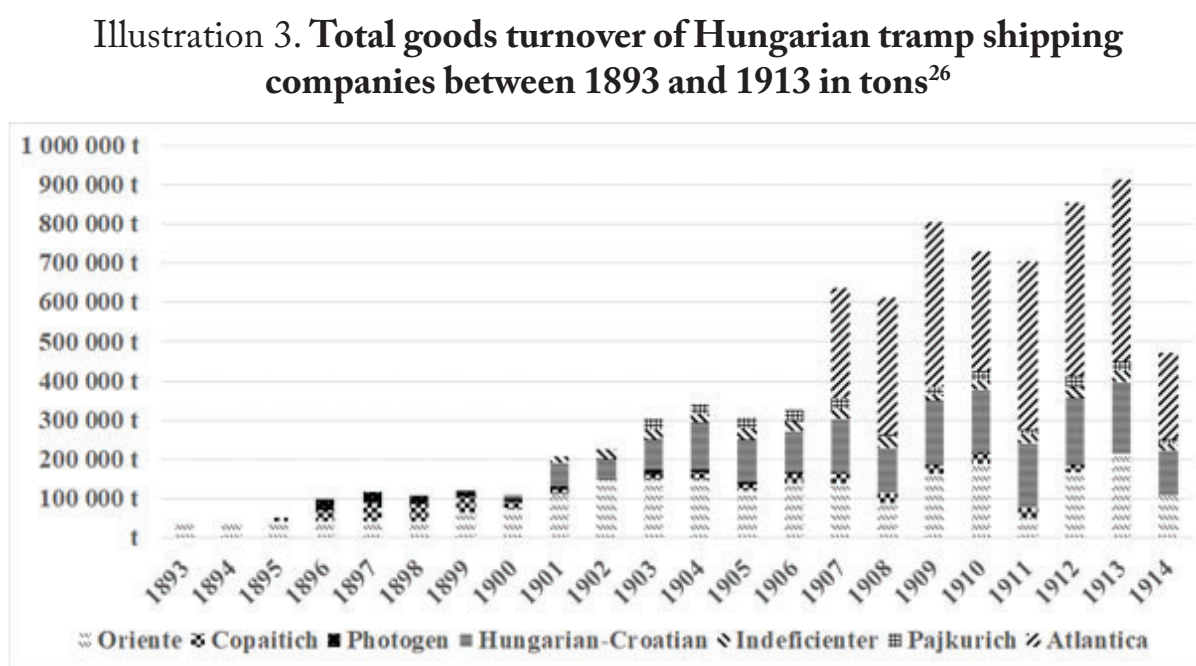

Source: Documents indicated in footnote 23. in the Rijeka State Archives from Atlantica and other tramp shipping company journals

25 Pelles, Márton-Zsigmond, Gábor: The Hungarian maritime...145-178.

${ }_{26}$ Goods turnover of 1914 naturally dropped due to the outbreak of WWI, hence only showing goods turnover between January and August 1914. 
This illustration clearly shows that even though the Atlantica was the tramp shipping company last founded, it could transport more goods $(2,912,162 \mathrm{t})$ than the two big companies Oriente $(2,315,956 \mathrm{t})$ and Hungarian-Croatian Company $(1,737,674 \mathrm{t})$. When investigating the turnover between 1907 and 1914, this advantage for Atlantica only increased. In this period the companies lost the following: 6 steamers of Oriente Co. 187,731 tons each, 6 steamers of Hungarian-Croatian Co. each 200,372 tons and the 12 steamers of Atlantica 242,680 tons each. This success of Atlantica was partly due to Polnay's innovative instruments and partly to the fact that the commercial agencies worked very efficiently. When the Atlantica ships arrived to whichever port, shipments were already waiting for them. This was the reason for the Atlantica ships barely ever traveling emptily, while in the case of the other Hungarian companies it was customary to return empty to the mother port of Fiume after delivery of a transport.

\section{Transformation of the company during the Great War (1914-1918)}

The outbreak of the War did not come as a surprise to the company. The Hungarian Ministry of Commerce warned the shipping companies through the Fiume Maritime Authority before the $28^{\text {th }}$ July 1914 to try to move their transports to the Mediterranean Sea in case of a war against Serbia. ${ }^{27}$ However, the war grew into worldwide proportions and this resulted in an uncomfortable situation for Atlantica. Atlantica's steamboats suffered the following fates when the War broke out: they tried to get home through enemy waters, they were captured in enemy ports or they tried to ship to neutral ports.

From the fleet the company sold SS Hunnia in Cardiff to the Russians on $3^{\text {rd }}$ April 1914. The SS Kossuth Ferencz arrived from Methil to Fiume on $26^{\text {th }}$ July 1914 with a load of coal. The SS Fiume arrived in Pula at the start of August with a load of coal. The SS Szterényi arrived to Fiume on $4^{\text {th }}$ August with coal from Newport, the SS Magyarország on $7^{\text {th }}$ August with coal from Penarth, the SS Gróf Khuen Héderváry on $7^{\text {th }}$ August with iron goods. The SS Polnay was taken as loot in Rotterdam by the British before the declaration of war. Because the ship was sunk during the war, they had to pay 50,000 English pounds indemnity after the war to Atlantica. ${ }^{28}$ The SS Gróf Serényi Béla left from Brăila with a shipment of cereals on $28^{\text {th }}$ July to Rotterdam and ensconced itself in Cartagena before the war. The SS Atlantica left from Odessa on $25^{\text {th }}$ July with a shipment of cereal to Rotterdam and moored in the neutral port of Ferrol. The SS Morawitz left Antwerp on $8^{\text {th }}$ July for Galveston, USA and did not return to Europe because of the war. The SS Budapest transported goods from Buenos Aires to Norfolk, USA and also stayed on the American continent. ${ }^{29}$ The latter two steamers were sold by Atlantica to the United States in 1915. Pursuant the laws on tramp shipping, the ships that made it back home had to be utilised for the war effort as determined by the Ministry of War. These were primarily transports of troops and goods. ${ }^{30}$

During the war the Austro-Hungarian navy was stuck in the Adriatic Sea resulting in commerce becoming practically entirely infeasible. Certain documents allude to the idea that the Governor of Fiume and the Fiume Maritime Authority urged the companies to have commercial submarines built, which would be able to get out of the Strait of Otranto. However, there is no further mention of this in the sources. ${ }^{31}$

\footnotetext{
27 Zsigmond, Gábor: Hungarian commercial maritime shipping in WW1. PhD dissertation. Miklós Zrínyi University of Defense, Lajos Kossuth Faculty of Military Sciences, Doctor School of Military Sciences Budapest. 2011. http://uni-nke.hu/downloads/konyvtar/digitgy/phd/2011/zsigmond_gabor.pdf

28 KEZ. 680.5.

29 DAR. 46: 733-1914-II-50.

30 Zsigmond, Gábor: Hungarian commercial...27-39.

31 DAR. 46: 859-1917-XI-235.
} 
In order to maintain commerce in the Adriatic Sea region, Atlantica purchased a steamer named Honvéd in 1917 with a capacity of 3,300 GRT and five sailboats with diesel engines. ${ }^{32}$ The ships named Szellö, Szélvész, Hullám and Orkán had a capacity of 220 GRT, the one named Zápor 450 GRT. These ships were primarily suited for smaller shipments between Fiume and East Adriatic ports.

The 1917 Atlantica general assembly documents refer to the fact that the company planned to build Danube sea-faring ships, concordantly the plans to make the bridges of Baja, Novi Sad (Serbia) and Sombor (Serbia) openable. ${ }^{33}$ Apart from this, Atlantica had a shipyard built for the production of Danube sea-faring ships, for which they purchased the Danube island named Háros, located next to Budapest. ${ }^{34}$ With the founding of this company in 1918 the Atlantica Sea Navigation Company Co. ceased to exist and its place was taken over by the newly founded Atlantica Trust. ${ }^{35}$

\section{Conclusion}

By investigating the activities of Atlantica Sea Navigation Company Co. between 1907 and 1914, we can state that by the ingenious managerial skills of Jenó de Polnay, he reached the goals as determined in the company statutes and by superseding these made the company the most successful Hungarian tramp shipping company. Jenő de Polnay can be merited for the fact that with the effective help of the Austro-Hungarian Bank and the Hungarian State Atlantica came into existence, and the fact that the redesign of the ships is attributed to his name so these could comply in the best manner for the shipment of timber. Through his contacts, he managed to get continual transports for the timber trade company of the Transylvanian Groedel family and Russian cereals from the Sea of Azov region. By transporting coal on the way back for the Hungarian State Railways he managed to employ his ships there and back again. But what was the most important innovation implemented by Polnay was the efficient introduction of the quick despatch principle in Hungary. This resulted in Atlantica's ability to load their ships faster and to increase efficiency.

Here, we also need to refer to the developed network of agencies that Atlantica operated. It maintained continual agencies in the bigger ports and in ports that were of importance to Atlantica. These agencies coordinated the planned transports between the major ports of the world. These activities added greatly to Atlantica Sea Navigation Company's efficiency.

The outbreak of the Great War greatly held back Atlantica's developments. However, in contrast to other Hungarian shipping companies, Atlantica quickly recognised potential and re-evaluated its own goals to start concentrating on river navigation to stay afloat even amidst the trying economic circumstances that followed World War I.

32 DAR. 46: 842-1917-I-1089.

33 DAR. 46: 844-1917-I-2702.

34 Herczeg, Renáta - Prakfalvi, Endre: Construction by the Atlantica Sea Navigation Company in the end-days of the Monarchy on Háros Island. Múemlékvédelem. 60. vol. 3-4 issue. 2016 207-230.

35 Hungarian National Archives. Z-1070: Atlantica Sea Navigation Company Co. 1887-1929. 